\title{
"Dialogue with stakeholders as a tool to ensure the sustainability of a business organization"
}

\begin{tabular}{|c|c|c|}
\hline AUTHORS & \multicolumn{2}{|l|}{$\begin{array}{l}\text { Taras Kytsak (D) } \\
\mathbb{R} \\
\text { Yurii Marshavin (D) } \\
\mathbb{R}\end{array}$} \\
\hline ARTICLE INFO & \multicolumn{2}{|c|}{$\begin{array}{l}\text { Taras Kytsak and Yurii Marshavin (2020). Dialogue with stakeholders as a tool to } \\
\text { ensure the sustainability of a business organization. Social and labour relations: } \\
\text { theory and practice, } 10(1), 21-24 \text {. doi:10.21511/sIrtp.10(1).2020.04 }\end{array}$} \\
\hline DOI & \multicolumn{2}{|c|}{ http://dx.doi.org/10.21511/sIrtp.10(1).2020.04 } \\
\hline RELEASED ON & \multicolumn{2}{|l|}{ Wednesday, 02 September 2020} \\
\hline RECEIVED ON & \multicolumn{2}{|l|}{ Thursday, 02 July 2020} \\
\hline ACCEPTED ON & \multicolumn{2}{|l|}{ Friday, 24 July 2020} \\
\hline LICENSE & \multicolumn{2}{|c|}{$\begin{array}{l}\text { This work is licensed under a Creative Commons Attribution } 4.0 \text { International } \\
\text { License }\end{array}$} \\
\hline JOURNAL & \multicolumn{2}{|c|}{ "Social and labour relations: theory and practice" } \\
\hline ISSN PRINT & \multicolumn{2}{|l|}{$2410-4752$} \\
\hline ISSN ONLINE & \multicolumn{2}{|l|}{ 2415-3389 } \\
\hline PUBLISHER & \multicolumn{2}{|c|}{ LLC "Consulting Publishing Company "Business Perspectives" } \\
\hline FOUNDER & \multicolumn{2}{|c|}{$\begin{array}{l}\text { State Higher Educational Establishment "Kyiv National Economic University } \\
\text { named after Vadym Hetman", Social and Labour Relations Institute }\end{array}$} \\
\hline$\sigma^{0}$ & 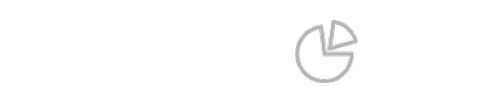 & 三ニ: \\
\hline NUMBER OF REFERENCES & NUMBER OF FIGURES & NUMBER OF TABLES \\
\hline 8 & 2 & 0 \\
\hline
\end{tabular}

(c) The author(s) 2022. This publication is an open access article. 


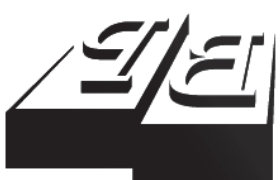

BUSINESS PERSPECTIVES

Publisher

LLC "CPC "Business Perspectives" Hryhorii Skovoroda lane, 10, Sumy, 40022, Ukraine www.businessperspectives.org

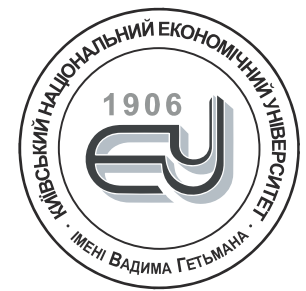

\section{HETMAN KNEU}

Founder

State Higher Educational Establishment "Kyiv National Economic University named after Vadym Hetman",

Prospect Peremogy, 54/1,

Kyiv, 03057, Ukraine

https://kneu.edu.ua/

Received on: 2nd of July, 2020 Accepted on: 24th of July, 2020 Published on: 2nd of September, 2020

(c) Taras Kitsak, Yurii Marshavin, 2020

Taras Kitsak, Ph.D. in Economics, Associate Professor, Personnel Management and Labor Economics Department, Kyiv National Economic University named after Vadym Hetman, Ukraine.

Yurii Marshavin, Doctor of Economics, Professor, Personnel Management and Labor Economics Department, Kyiv National Economic University named after Vadym Hetman, Ukraine.

\section{(c) (i)}

This is an Open Access article, distributed under the terms of the Creative Commons Attribution 4.0 International license, which permits unrestricted re-use, distribution, and reproduction in any medium, provided the original work is properly cited.
Taras Kitsak (Ukraine), Yurii Marshavin (Ukraine)

\section{DIALOGUE WITH STAKEHOLDERS AS A TOOL TO ENSURE THE SUSTAINABILITY OF A BUSINESS ORGANIZATION}

\begin{abstract}
The paper examines conceptual principles and the significance of dialogue with stakeholders for the successful functioning of a business organization, its development, competitive advantage, sustain ability, brand and image growth. The relevance of this concept in new business realities, the main trends of which are digitalization, openness, networking, and globality of processes, has been substantiated. The purpose of the study is to establish the impact of dialogue with stakeholders on the social and economic development of a business organization in the realities of the new economy. In the course of researching theoretical approaches regarding the nature and scope of dialogue with stakeholders, the author has formed his own point of view on the value and relevance of these processes for business organizations; personal understanding of their impact on business and society has been determined. A list of potential opportunities for a business organization was identified and supplemented, subject to establishing an effective dialogue with stakeholders based on social responsibility. The author's vision of the content and essence of the stakeholder engagement policy has been developed, the effectiveness of which will manifest itself in increasing the company's capitalization, improving sustainability, and increasing investment attractiveness. Possible areas of manifestation and directions of interaction with stakeholders have been analyzed and the prospects and opportunities for their development towards strengthening the business process sustainability have been outlined. The research on the importance of dialogue with stakeholders for Ukrainian companies has been analyzed. Conclusions regarding the prospects for the development of this concept in the direction of improving business processes have been substantiated.
\end{abstract}

Keywords

competitiveness, dialogue with stakeholders, social responsibility, social investment, new economy

JEL Classification

A13, L14, M14

Т. Г. Кицак (Україна), Ю. М. Маршавін (Україна)

\section{ДІАЛОГ ЗІ СТЕЙКХОЛДЕРАМИ ЯК ІНСТРУМЕНТ ЗАБЕЗПЕЧЕННЯ СТІЙКОСТІ БІЗНЕС-ОРГАНІЗАЦІЇ}

\begin{abstract}
Анотація
У статті досліджено концептуальні засади та значущість діалогу зі стейкхолдерами для успішного функціонування бізнес-організації, іiі розвитку, забезпечення конкурентних переваг, стійкості, зростанню бренду та іміджу. Обгрунтовано актуальність цього концепту в нових бізнес-реаліях, головними трендами яких є цифровізація, відкритість, мережевість, глобальність процесів. Метою дослідження $\epsilon$ встановлення впливу діалогу з зацікавленими сторонами на соціально-економічний розвиток бізнес-організації в реаліях нової економіки. При дослідженні теоретичних підходів відносно сутності та сфери прояву діалогу зі стейкхолдерами сформовано власну точку зору про цінність та актуальність цих процесів для бізнес-організації, визначено власне розуміння їх впливу на бізнес і суспільство. Визначено і доповнено перелік формування потенційних можливостей для бізнес-організації при умові налагодження ефективного діалогу з зацікавленими сторонами на засадах соціальної відповідальності. Розроблено власне бачення змісту і сутності політики взаємодії зі стейкхолдерами, результативність якої матиме прояв у підвищенні капіталізації компанії, покращенні стійкості, зростанні інвестиційної привабливості. Проведено аналіз можливих сфер прояву та напрямів взаємодії з зацікавленими сторонами та окреслено перспективи та можливості їх розвитку у напрямі посилення стійкості бізнес-процесів. Проведено аналіз дослідження на предмет вагомості діалогу зі стейкхолдерами для українських компаній. Обгрунтовано висновки стосовно перспектив розвитку цього концепту у напрямі досконалення бізнес-процесів.
\end{abstract}

Ключові слова

конкурентоспроможність, діалог зі стейкхолдерами, соціальна

Класифікація JEL 


\section{ВСТУП}

Вумовахстановленняцифровоїекономіки, розвиткуінформаційнихтехнологій,посилення ролісоціальної сфери, поширення відкритості та прозорості бізнес-процесів, все більше компаній усвідомлюють те, що орієнтація на збільшення акціонерного капіталу та підвищення фінансових показників не дає відчутного результату. Інші сфери потребують більшої уваги та концентрації інноваційних та креативних підходів до вирішення проблем господарської діяльності. Діалог зі стейкхолдерами являється одним з головних напрямів розвитку та забезпечення конкурентоспроможності бізнес-організації. Взаємодія 3 зацікавленими сторонами сприяє інноваційності створених продуктів і організації виробничих процесів у напрямі посилення генерації інноваційних рішень, які впливатимуть на стійкість та конкурентоспроможність бізнес-організації у зовнішньому та внутрішньому середовищі.

\section{1. ЛІТЕРАТУРНИЙ ОГЛЯА}

В процесі аналізу наукових поглядів на проблему організації ефективної взаємодії бізнес-організації 3 головними стейкхолдерами формується думка про те, що запорукою стійкості бізнес-процесів є якісна оцінка середовища діяльності компанії за допомогою аналізу інтересів та очікувань основних суб’єктів, зацікавлених у результатах діяльності бізнес-структури. Ці переконання також підтверджуються практичними дослідженнями, які показують, що налагодження ефективної взаємодії бізнес-організації з її головними стейкхолдерами сприяє формуванню достовірних уявлень про якість власних бізнеспроцесів, оцінці ризиків та пошуку нових можливостей забезпечення досягнення стратегічних цілей. Результати оцінювання інтересів та пріоритетів головних стейкхолдерів сприяють утвердженню базових цінностей діяльності бізнес-організації, визначенні місії та розробці генеральної стратегії. Відомі науковці визначають концептуальні засади діалогу компанії зі стейкхолдерами, перш за все, з точки зору його впливу на ефективність діяльності бізнес-організації, яка може бути забезпечена завдяки покращенню репутації, іміджу; залученню нових партнерів та інвестицій; покращенню якості продуктів та послуг, які відповідають запитам стейкхолдерів; поліпшенню прийняття управлінських рішень та удосконалення комунікацій; розвитку партнерських взаємовідносин зі споживачами. Орієнтовний перелік головних стейкхолдерів компанії: власники, споживачі, акціонери, персонал, топ-менеджмент, 3МІ, конкуренти, громадські організації, постачальники, органи державної влади, територіальні громади.

Вперше в науковому світі проблему взаємодії зі стейкхолдерами розглянув американський учений Фрімен у свої праці «Strategic Management: A Stakeholder Approach» у 1984 році. Висунута ідея Фрімена про те, що інтереси і вимоги зацікавлених сторін мають враховуватись менеджментом організації при прийнятті стратегічних рішень отримала вагому підтримку в наукових колах. При друку його монографії всього в десяти примірниках, протягом восьми років кількість статей на цю проблематику сягала вже більше ста двадцяти. Саме ідея Фрімена про розуміння сутності поняття «stakeholder», яка полягала у виокремленні суб’єктів що впливають на діяльність організації та піддаються будь-якому ії впливу, набула загальносвітового поширення. Як зазначав Фрімен, дії, інтереси і активність суб’єктів, які здійснюють вплив або піддаються впливу компанії в процесі досягнення нею стратегічних цілей та інтересів, не повинні ігноруватися, а їх вплив, прямий чи опосередкований, має бути врахований при прийнятті управлінських рішень, формуванні планів розвитку та політик успішної діяльності та процвітання. Інтереси і потреби стейкхолдерів мають бути дослідженими, вивчені і проаналізовані для того, щоб стійкість розвитку бізнес-організації мала підтримку зі сторони головних зацікавлених сторін [5].

Актуальна цінність цієї концепції в сучасних умовах набуває все більшого значення, оскільки реалії глобалізації, інформатизації та цифровізації всіх сфер життєдіяльності головних суб’єктів суспільної взаємодії посилює активність бізнес-організації у площині налагодження інноваційних комунікацій 3 тими, хто має будь-який інтерес до діяльності компанії, впливає на ї̈ стійкість, конкурентоспроможність, бренд, імідж, капіталізацію та інноваційний розвиток. Серед інших науковців, які розвивали теорію стейкхолдерів з точки зору розуміння концепту поняття її сутності можна виділити Кларксона, Грея, 
Бачхолца, Керола. Методи оцінювання та аналізу інтересів стейкхолдерів розглядались у працях Маркуса, Дональдсона, Чайдла, Престона. Відомими є наукові праці Баклеса, Вуда, Діпхауза, Магнеса, Брайсона, які суттєво удосконалили методи системного аналізу та досліджували поведінку головних суб'єктів, які зацікавлені у результатах діяльності компанії.

Концептуальні засади побудови стратегії взаємодії зі стейкхолдерами були розглянуті у працях таких дослідників як Саванж, Роулі, Фрумен.

Відомий дослідник, перший директор Центру корпоративної соціальної відповідальності та етики факультету менеджменту Університету міста Торонто, Кларксон визначив концепт організації діалогу з зацікавленими сторонами за такими основоположними базовими принципами:

- топ-менеджери мають активним чином розвивати ідею налагодження співпраці зі стейкхолдерами, розвивати політику налагодження ефективних комунікацій, враховувати інтереси головних зацікавлених сторін при прийнятті управлінських рішень;

- керівники бізнес-організації повинні враховувати ініціативи зацікавлених сторін, налагоджувати 3 ними тісні контакти, організовувати відкритий діалог для обговорення потенційних проблем і можливостей подальшої співпраці, з урахуванням потенційних ризиків і загроз;

- процеси, принципи та моделі поведінки необхідно формувати відповідно до інтересів та вимог зацікавлених сторін;

- керівництво бізнес-організації має усвідомлювати взаємозалежність своїх дій і потенційних результатів, які залежатимуть від впливу зацікавлених сторін, тому необхідно раціонально розподіляти серед головних стейкхолдерів зобов’язання та зиски, орієнтуючись на ризики вразливості зацікавлених сторін;

- топ-менеджери відповідно мають налагоджувати ефективну співпрацю з головними стейкхолдерами для запобігання та мінімізації потенційних ризиків і збитків, і в разі неможливості їх уникнення, забезпечити гідну компенсацію втрат;

- $\quad$ керівники бізнес-організації мають унеможливити виникнення проблем усфері порушення основних прав та свобод громадян, що потенційно може створити ряд загроз та ризиків у майбутньому;

- власники компанії повинні передбачати можливість виникнення конфліктних ситуацій, предметом яких може бути їх власна поведінка, яка викликана поведінкою головної з зацікавлених сторін; а також мають враховувати необхідність прояву соціальної, екологічної та економічної відповідальності по відношенню до інших стейкхолдерів [2].

Вагомий внесок у дослідження сутності процесу організації ефективної взаємодії компанії зі стейкхолдерами за допомогою розробки моделі ідентифікації значущості зацікавлених сторін реалізували відомі науковці Мітчел, Егл і Вуд. Вони виділили сім груп стейкхолдерів (владні; домінуючі; неактивні; категоричні; небезпечні, залежні; вимогливі; важливі) та розробили цілісну концепцію ідентифікації і класифікації зацікавлених сторін на основі трьох найбільш значущих ознак: легітимність, владність, терміновість. Головною особливістю моделі Мітчела, Егла і Вуда $€$ те, що ознаки кожного стейкхолдера не мають чітко фіксованого часового проміжку, оскільки їх властивості можуть змінюватися, що вимагатиме кардинально інших активностей менеджменту бізнес-організації. Це також було підтверджено рядом практичних перевірок та емпіричними дослідженнями, які підтвердили залежність між ознаками стейкхолдерів та рівнем іх значущості. Висновки стосовно пріоритетності кожної ознаки були різні. Наприклад Агл визначає терміновість головним пріоритетом значущості зацікавлених сторін; Перент і Дипхауз віддають першість владі; Магнес вважає, що найбільш вагомою ознакою є легітимність [7].

Отже, літературний огляд підтверджує наукові висновки про те, що діалог зі стейкхолдерами є важливим фактором та імперативом, який визначає можливості забезпечення стійкісті, конкурентоспроможності, бренду, іміджу, капіталізації та інноваційного розвитку бізнес-структури. Менеджмент компаній має задіяти ряд практик з управління комунікаційною спроможністю взаємодії зі стейкхолдерами, враховуючи генеральну стратегію, місію, мету та цілі діяльності бізнес-організації. Ці висновки підтверджуються також засновником теорії зацікавлених сторін Фріменом, який акцентує увагу на тому, 
що довгостроковий успіх компанії у турбулентному і динамічному ринковому середовищі може бути забезпечений за рахунок того, що менеджмент організує взаємодію зі стейкхолдерами у відповідності з власною стратегією, цілями та власними можливостями, що і забезпечить результати і вигоди як для компанії, так і для головних зацікавлених сторін [5].

Практична цінність розглянутих наукових підходів щодо теорії стейкхолдерів проявляється у тому, що в процесі налагодження ефективної взаємодії з зацікавленими сторонами менеджмент бізнес-організації має орієнтуватись на їх інтереси та потреби, і в результаті впровадження комплексних практик з їх оцінювання, формувати політику налагодження ефективного діалогу з головними стейкхолдерами у напрямі зростання капіталізації, посилення конкурентоспроможності, покращення бренду та іміджу.

Метою дослідження $є$ обгрунтування впливу діалогу зі стейкхолдерами на стійкість розвитку бізнес-організації.

\section{2. РЕЗУЛЬТАТИ}

В умовах наростаючої загрози зміни клімату, глобалізації економічних відносин, тенденцій та трендів діджиталізації, сучасні суспільства зустрічаються з рядом економічних, соціальних та екологічних викликів. Прослідковується зростання активностей у сфері формування громадянського суспільства, що пояснюється розвитком нових комунікаційних технологій, зміною звичного укладу життєдіяльності, наявністю соціально-економічних проблем. В результаті прояву цих тенденцій зовнішнє середовище діяльності компаній продукує ряд загроз та проблем, які загрожують стабільності та упевненості у завтрашньому дні. В багатьох країнах бізнес-структури відіграють активну роль у побудові та удосконаленні державної політики та державного регулювання, підвищується роль приватного сектору у забезпеченні традиційних державних функцій. Іншим трендом сучасності є зростання ролі корпорацій, які формують нові правила і принципи поведінки державних та недержавних структур на міжнародному рівні.

Відповідно до зростання суспільної вагомості бізнесових структур починають зростати і вимоги від представників різних соціальних груп, які відчувають як вплив діяльності компаній, так і наявність інтересу та вимог до результатів їх діяльності. Такі суб’єкти висувають ряд цілком виправданих вимог відносно того, що транснаціональні корпорації мають інформувати про свою діяльність, її вплив на навколишнє середовище, соціальну та економічну сферу. Щодо території присутності виробничих процесів, за вимогами цих суб’єктів, мають відбуватись консультації при прийнятті важливих рішень які матимуть потенційні наслідки та ризики для територіальної громади та інших зацікавлених сторін у соціальній, економічній та екологічній сфері.

Тому більшість компаній змінили своє ставлення до взаємодії з головними суб’єктами, які представляють ряд інтересів та вимог до компанії з приводу соціальних та економічних проблем, питань збереження ресурсів навколишнього середовища. Питання взаємодії з головними стейкхолдерами бізнес-структури імплементували в систему організаційного управління, передбачивши активний та партнерський діалог, удосконалили та систематизували підходи до вирішення проблемних питань, налагодили комунікаційні платформи для взаємодії. Ці активності сприяють зростанню партнерських взаємодій, напрацюванні спільних рішень, управлінні ризиками, ефективному вирішенню конфліктних ситуацій.Провіднікомпанії активно оцінюють взаємодію зі стейкхолдерами як інструмент, що сприяє продукуванню інноваційних рішень у створенні нових бізнес-продуктів і організації удосконалених технологічних процесів, які направлені на посилення стійкості у внутрішньому та зовнішньому середовищі. Ефективність діалогу з зацікавленими сторонами спонукає керівників бізнес-структур до консолідації ресурсів відповідно загальноприйнятій стратегії, сприяє вирішенню проблем та досягненню цілей, які не мали 6 такого рівня результативності за інших умов. Крім цього інші учасники такої взаємодії отримують можливості для реалізації особистих цілей та забезпечення інтересів, які вони 6 не змогли досягнути діючи самостійно. 
Структурний склад головних стейкхолдерів сучасних компаній наступний:

- внутрішні - акціонери, власники, топ-менеджмент, персонал;

- зовнішні - споживачі, територіальні громади, постачальники, органи державної влади, 3MI, громадські організації, конкуренти.

Необхідно акцентувати увагу та тому, що ці зацікавлені суб’єкти володіють достатньо широким набором інтересів і потреб, які через певний проміжок часу можуть зазнавати змін як стосовно змістовності так і відносно їх пріоритетності. Але, незважаючи на такі тенденції, багаточисленні наукові дослідження та практики оцінювання потреб зацікавлених суб'єктів сприяли встановленню тісного зв’язку стійкості бізнес-організаціїз налагодженням ефективноїспівпраціз зацікавленими сторонами. Цепідтверджується тими фактами, що компанії, які займають лідируючі позиції, визначають взаємодію зі стейкхолдерами як впливовий інструмент сприяння розробці інноваційних продуктів та технологічних удосконалень. Процеси співробітництва 3 зацікавленими сторонами також сприяють гармонізації економічних, соціальних та екологічних сфер відносно стратегії організаційного розвитку, а також вимагають розробки політики залучення людських та фінансових ресурсів для реалізації визначених пріоритетних потреб стейкхолдерів, які, в свою чергу, тісно пов’язані з діяльністю компанії та сприятимуть реалізації визначених завдань. Менеджмент компаній також все більше усвідомлює переваги та зиски для компанії від процесу налагодження ефективного діалогу зі стейкхолдерами з застосуванням принципів, цінностей та практик соціальної відповідальності, концепт якої формує основні правила та процедури реалізації основних ідей та цілей. Потенційні зиски для компанії матимуть прояви у наступному:

- поліпшення стійкості соціальної взаємодії в процесі залучення зацікавлених сторін до прийняття стратегічних рішень за принципом соціальної справедливості;

- у удосконалення оцінювання зовнішнього середовища компанії та як результат - розвиток стратегічних можливостей завдяки дослідженню змін ринкової кон'юнктури;

- удосконалення бізнес-процесів у процесі обробки інформації про стейкхолдерів та їх пріоритети;

- поліпшення бренду та іміджу компанії завдяки реалізації соціально відповідальних практик, які орієнтовані на потреби зацікавлених сторін;

- зміцнення лідерських позицій динамічному і конкурентному середовищі;

- розробці ефективних стратегій домінування у ринкових сегментах;

- розвиток компанії у відповідності з трендами та принципами сталого розвитку.

Відповідно до стандарту ISO 26000 (керівництво з соціальної відповідальності), виявлення стейкхлдерів і взаємодія з ними є головним елементом реалізації соціальної відповідальності компанії. Перелік головних стейкхолдерів для кожної компанії може мати свою особливість щодо їх кількості та статусів важливості, оскільки це залежить від сфери та обсягів діяльності компанії, регіону присутності, специфіки господарської діяльності та технологій виробничих процесів.

Взаємовідносини компаній зі стейкхолдерами можуть також бути закріплені юридичними договорами, законодавчими нормами країни присутності, міжнародними документами (Загальна декларація прав людини, Конвенції Міжнародної організації праці, Міжнародним пактом про економічні, соціальні і культурні права). Для прикладу можна привести тезис «Зеленої книги» $Є С$, яким проголошено, що всі зацікавлені сторони мають право бути почутими [4].

В Україні тільки починає формуватись експертне середовище, яке оцінює та популяризує практики соціальної відповідальності, основним концептом якої $є$ діалог з зацікавленими сторонами. Керівник «Центру корпоративної соціальної відповідальності», провідної структури з розвитку соціальної відповідальності бізнесу, акцентує увагу на тому, що взаємодія зі стейкхолдерами сприяє формуванню місії, стратегії; поліпшенні якості товарів та послуг; розвитку інновацій; дозволяє об’єднувати ресурси в процесі досягнення цілей; створює соціальний капітал та покращує партнерські взаємовідносини [8].

Конструкт реалізації політики взаємодії зі стейкхолдерами має включати ряд етапів (Таблиця 1). 
Етап 1. Аналіз зовнішнього середовища компанії, визначення переліку головних стейкхолдерів

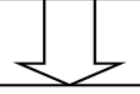

Етап 2. Оцінювання інтересів головних стейкхолдерів та їх впливу на компанію, встановлення їх значущості

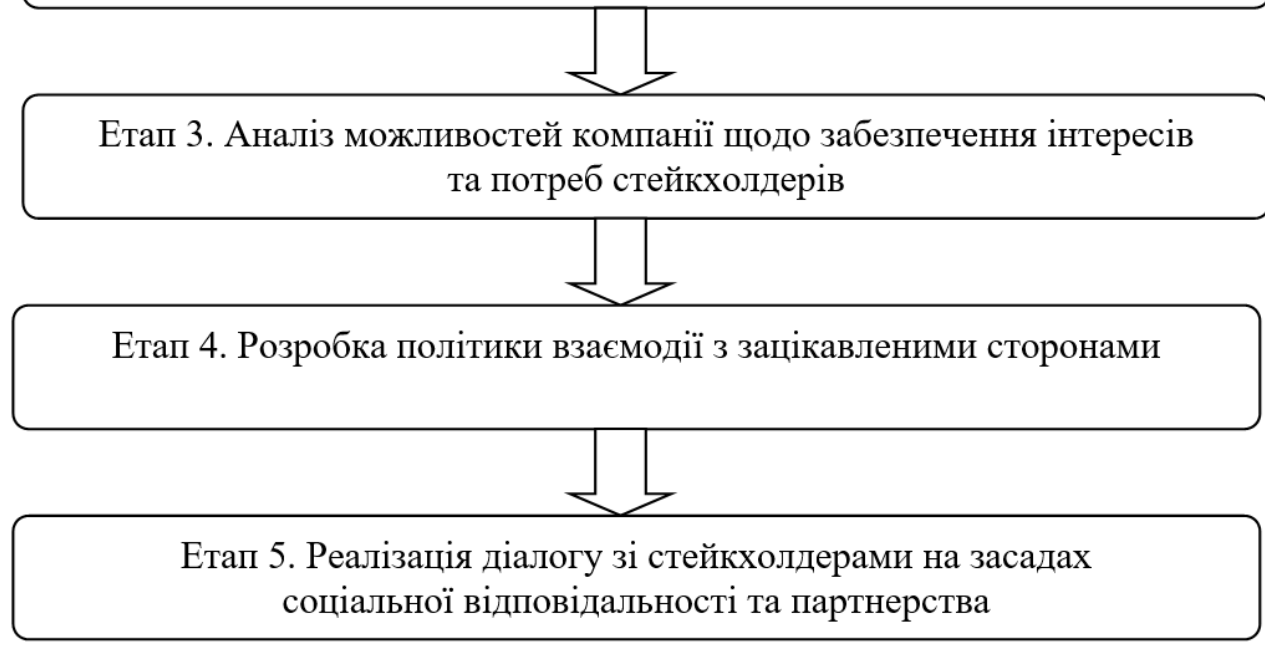

Джерело: Розроблено автором.

\section{Рисунок 1. Етапи взаємодії компанії зі стейкхолдерами}

Зміст реалізації політики взаємодії зі стейкхолдерами на кожному з етапів для різних компаній має свої особливості. Великі компанії більше уваги приділяють взаємодії з головними зацікавленими суб'єктами, що обумовлено наявністю матеріальних ресурсів, які нівелюють вплив другорядних стейкхолдерів. Середні і дрібні бізнес-організації майже не приділяють концепту діалогу зі стейкхолдерами вагомого значення, оскільки не мають розвинутого апарату корпоративного управління, менш залежні від трендів глобалізації, не розвивають практики соціальної відповідальності та пов’язані з нею активності у вигляді публікацій соціальних звітів, де вагомою їх змістовною частиною являється опис діалогу з зацікавленими сторонами.

Але хоча малий і середній бізнес не проявляє активностей у цих сферах, ті чи інші соціально відповідальні процедури та активність у напрямі взаємодії з окремими зацікавленими сторонами на практиці реалізує. Тому, підсумовуючи вищеописані дослідження, узагальнений конструкт визначення стейкхолдерів з їх ідентифікацією представлені на Рисунку 2.

В результаті ідентифікації головних стейкхолдерів компанії має бути розроблена політика ефективної взаємодії, яка передбачатиме наступні процеси:

- формування стратегії управління зацікавленими сторонами та визначення ключових показників взаємодії;

- формування робочої групи з визначенням сфер діяльності (HR департамент, відділ зовнішніх зв’язків, PR департамент та ін.);

- визначення пріоритених напрямів взаємодії зі стейкхолдерами;

- реалізація активної стратегії взаємодії з розширенням використання сучасного інструментрію (цифрові технології, соціальні мережі, інтернет);

- с створення платформи ефективної взаємодії з використанням IT - технологій (онлайн-чати, електронні опитування);

- розширення можливостей взаємодії за допомогою публікації соціальної звітності згідно міжнародних стандартів;

- оцінювання якості взаємодії за попередній період згідно реалізованих практик та процедур. 


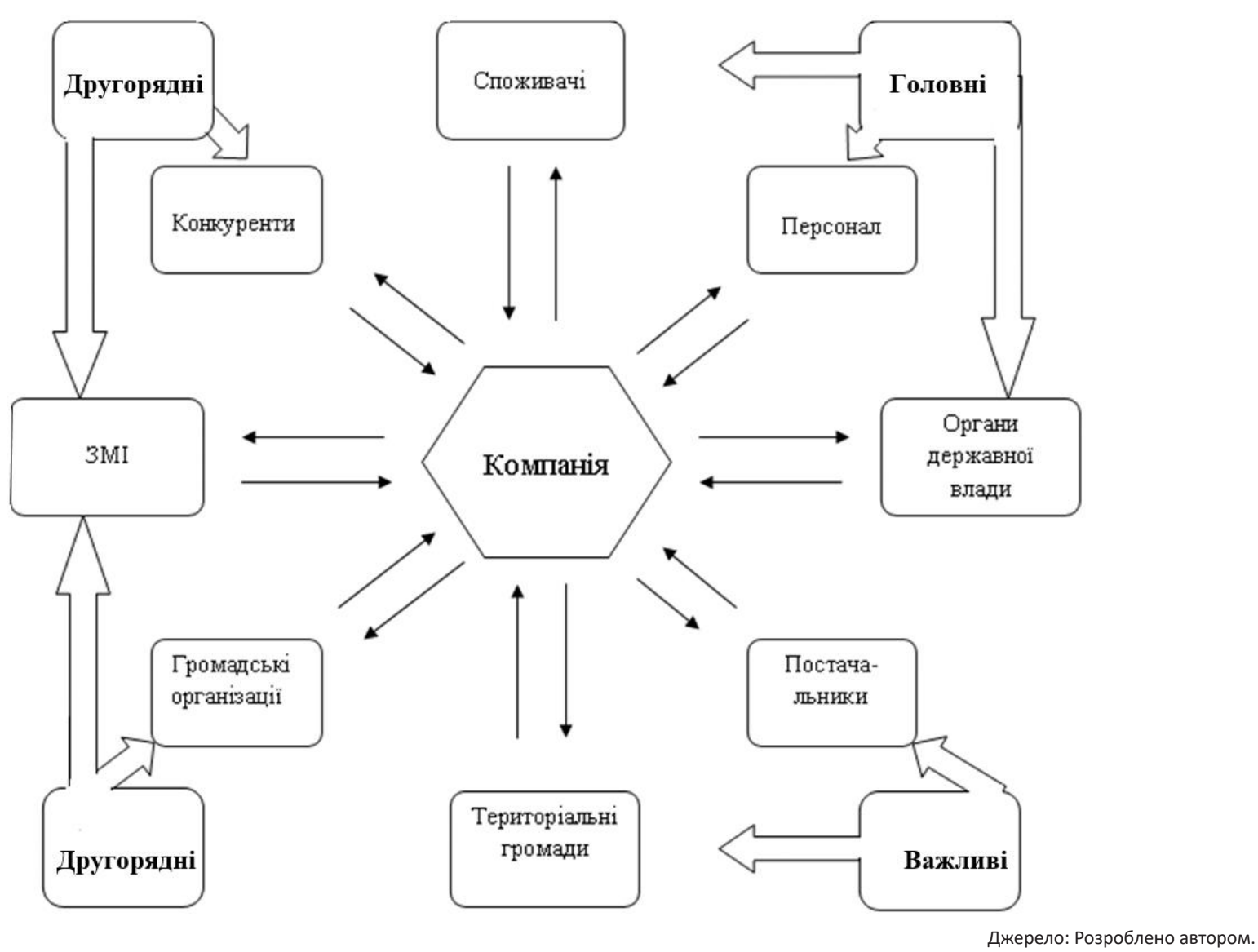

Рисунок 2. Стейкхолдери компанії та їх ідентифікація

Отже, взаємодія компанії з головними зацікавленими сторонами свідчить про їі готовність активно інвестувати у свій власний розвиток, у розвиток персоналу та споживачів, постачальників та партнерів; формувати передумови стійкого розвитку; сприяти процвітанню територіальних громад, реалізуючи соціальні інвестиції за напрямами, які є важливими для їх життєдіяльності; проявляти готовність до активної партнерської взаємодії з тими суб’єктами, які володіють потенціалом впливу на стабільність бізнес-процесів компанії. Формування широкого кола міжсуб’єктної взаємодії з активним задіянням практик стейкхолдерської ідентифікації забезпечує додатковий підприємницький ефект та розвиває новий сегмент активностей, відповідно забезпечуючи нові зиски та результати.

Діалог зі стейкхолдерами являється концептуальною засадою функціонування та прогресивного розвитку бізнес-організацій у 21 столітті. Тому ряд успішних компаній, популяризуючи власну корпоративну культуру, засновану на цінностях та пріоритетах сталого розвитку, сприяє формуванню середовища підтримки та контролю концептуальних засад взаємодії бізнес-організації з її зацікавленими сторонами.

\section{ВИСНОВКИ}

Розвиток компанії в сучасних умовах нестабільності, невизначеності, мінливості та непередбачуваності бізнес-середовища може мати практичну ефективну реалізацію завдяки тому, що будуть проведені зміни у підходах до формування філософії, генеральної стратегії, місії та головних цілей діяльності. Докорінні зміни принципів та стандартів партнерських відносин, розвиток етичних цінностей, зростання ролі соціальної сфери, поява нових методів та форм посилення конкурентоспроможності вимагають активного впровадження діалогу зі стейкхолдами, який розвиватиметься завдяки проведенню якісного оцінювання їх інтересів та потреб, формуванні політики їх забезпечення з орієнтацією на власні цілі та стратегічні орієнтири. Головними елементами процесу діалогу з зацікавленими сторонами 
постануть питання бізнес-етики та соціальної відповідальності, діагностики діяльності компанії в сукупності економічних, екологічних та соціальних аспектів, які формуватимуть тісні зв’язки зі стейкхолдерами на умовах узгодженності дій та синергії результатів. Активне використання концепту стейкхолдерів в управлінській та господарській практиці видозмінюватиме модель бізнесу, наповнюючи іï підприємницьким та інноваційним змістом, що сприятиме довготривалому домінуванні компанії у ринковому сегменті.

\section{AUTHORS CONTRIBUTIONS}

Conceptualization: Taras Kitsak, Yurii Marshavin.

Data curation: Taras Kitsak.

Methodology: Taras Kitsak, Yurii Marshavin.

Project administration: Taras Kitsak.

Resources: Taras Kitsak, Yurii Marshavin.

Supervision: Taras Kitsak.

Writing - original draft: Taras Kitsak.

Writing - review \& editing: Taras Kitsak, Yurii Marshavin.

\section{СПИСОК ЛІТЕРАТУРИ}

1. AccountAbility (2005). Standart vzaimodeystviya s zainteresovannymi storonami AA1000SES [AA1000 Stakeholder Engagement Standard]. (In Russian). Retrieved from https://cutt.ly/EsPMqfz

2. Clarkson, M. (1995). A Stakeholder Framework for Analyzing and Evaluating Corporate Social Performance. The Academy of Management Review, 20(1), 92-117. http://dx.doi.org/10.2307/258888

3. Druker, P. (2012). Menedzhment. Vyzovy XXI veka [Management. Challenges of the XXI century]. Moscow: Mann, Ivanov i Ferber. (In Russian)

4. European Commission (2010). Sustainable and responsible business. Corporate Social Responsibility (CSR).

5. Freeman, E. (2012). Strategic Management: A Stakeholder Approach. Boston: Pitman.

6. ISO (n.d.). ISO 26000:2010 Guidance on social responsibility. Retrieved from https://www.iso.org/standard/42546.html

7. Mitchell, R., Agle, B., \& Wood, D. (1997). Toward a theory of stakeholder identification and salience: Defining the principle of who and what really counts. The Academy of Management Review, 22(4), 853-886. Retrieved from http://www.jstor.org/stable/259247

8. Saprykina, M. (2011). Korporatyvna sotsialna vidpovidalnist : modeli ta upravlinska praktyka [Corporate social responsibility: models and management practice] (470 p.). Kyiv: Fabovanyi lyst. 